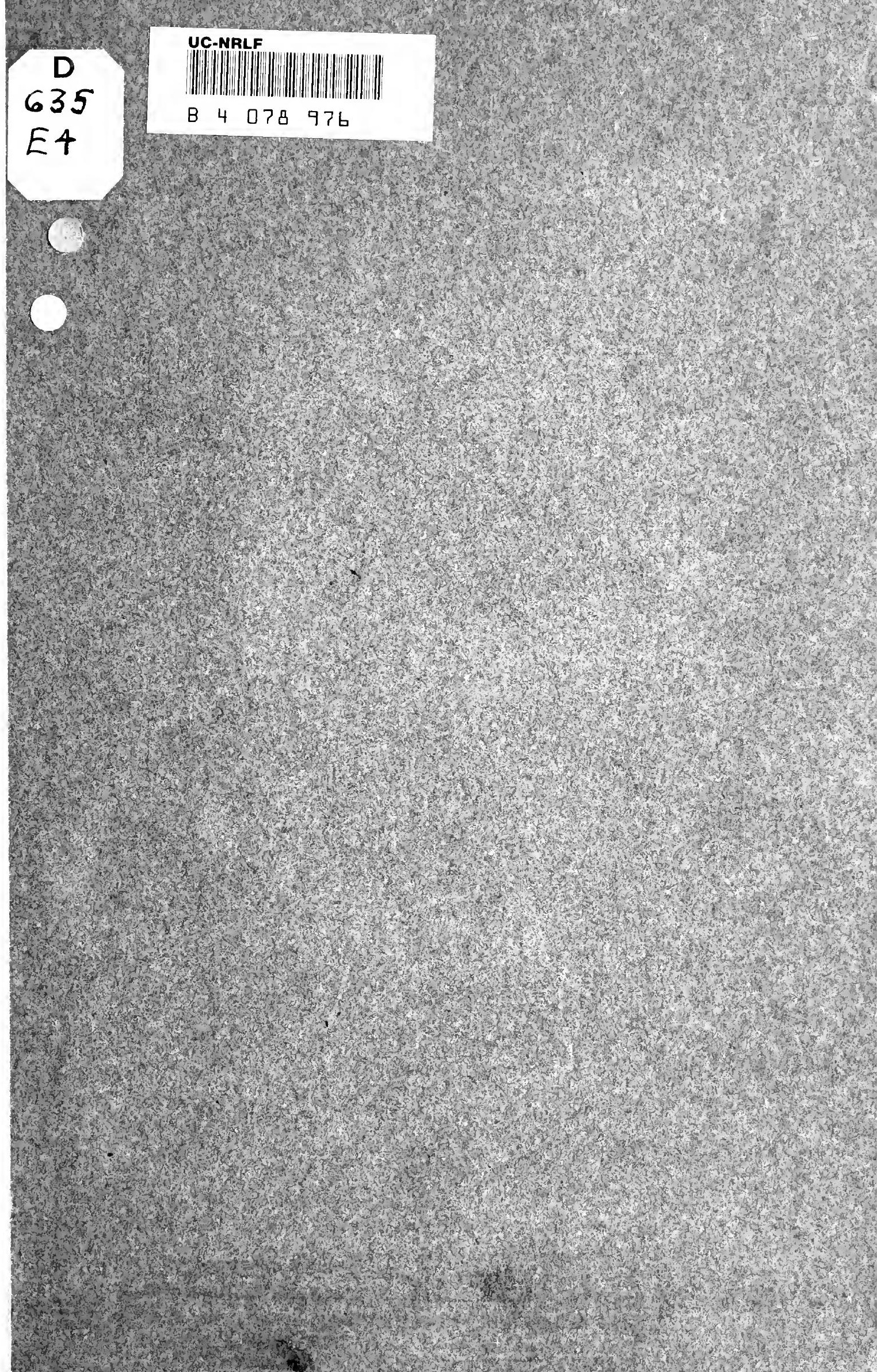



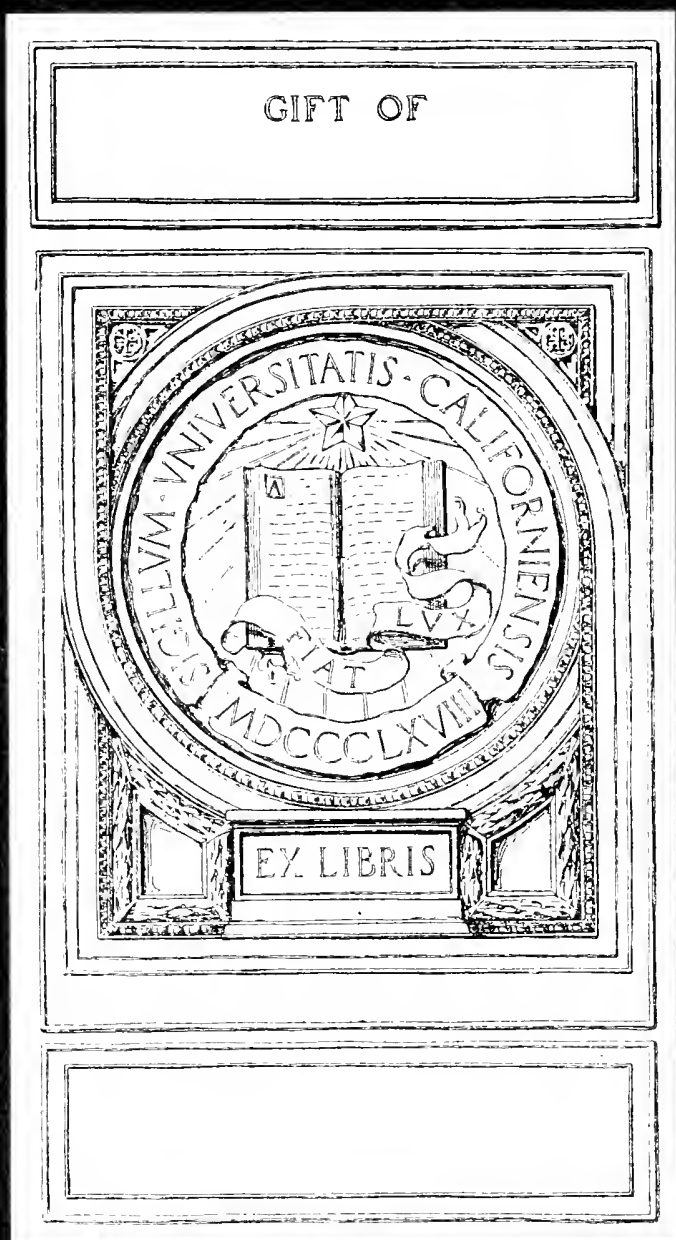


\section{British Emergency Legislation During the Present War}

\section{By LUDWIK EHRLICH}

(Reprinted from California Law Review of September, 1917) (Revised and carrected edition) 
COPYRIGHT, 1917

By LUDWIK EHRLICH 


\section{British Emergency Legislation During the Present War'}

\section{$\mathrm{I}^{\mathrm{E}}$}

THERE were any need of proving that England did not provoke or desire the present war, no proof could be more conclusive than the general state of unpreparedness when the war was actually declared. The number of measures which had to he taken immediately at the outbreak of the war, though large in itself, is small as compared with the additions which experience proved to be necessary in order that the war might be prosecuted to a successful finish. The need for new measures arose, first, as the government became aware of the insufficiency of the existing rules; and secondly, as modern warfare brought with it the necessity of providing for new emergencies.

Under the old common law ${ }^{2}$ there had, at the outbreak of the war, existed rules which gave the King, or, in other words. the government, a certain amount of power. Here might be mentioned the right to require, in case of sudden invasion or dangerous rebellion, the personal services of every man capable of bearing arms, the right to regulate intercourse between British and foreign subjects, to exclude, or place restrictions upon, aliens, to restrain subjects from leaving the country or to recall them from abroad, to place an embargo upon shipping, to make proclamations to a certain extent for the trial of civilians by court-martial, to enter private land in order to erect fortifications, etc. Statutes passed during the nineteenth century had also conferred upon the government compulsory powers. But, at the outbreak of the present war, it proved necessary to build up a practically new system of emergency legislation. That was done first of all by statutes. ${ }^{3}$ Statutes, however, could only confer general powers, and the working out of details was left to procla-

1 A lecture delivered at the University of California on April 20, 1917. Some later developments are referred to in the foot-notes.

2 Cf. Halsbury, Laws of England, vi. p. 444, s. v. Constitutional Law.

3 These statutes can be found in the general collections of British statutes (the official collection "Public General Acts," or "Law Reports: The Public General Statutes," or "Law Journal Reports: The Public General Acts", or "Law Times: Statutes"). A collection, under the title Manual of Emergency Legislation, was published in September, 1914, with, so far as the writer knows, four supplements (to August 31, 1915): it includes 
mations or Orders in Council made by the King, (corresponding to the proclamations of the President of the United States), or even to orders of certain other authorities, such as departments of government, e.g. the Board of Trade, the Home Secretary, the Secretary for Scotland, or the "Competent Military Authority" under the Defence of the Realm Regulations.

It might be useful to discuss the statutes and other rules enacted during the war under the following heads: (a) Organization of Forces. (b) Supplies for the Forces. (c) Prevention of Demoralization and Maintenance of Order. (d) Protection of the Country. (e) Weakening of the Economic Power of the Enemy. (f) Strengthening of the Economic Power of the Country.

Of course only the most important and characteristic enactments can be referred to here and financial measures will have to be left out almost entirely.

\section{Organization of the Forces.}

The first steps to be taken were the making of decrees calling out the reserve and otherwise providing for the use of all existing forces of the Crown. The original British army, as it existed at the outbreak of the war, proved very small indeed in comparison with the forces which have since been organized and sent to the front. Apart from the voluntary recruits, it was found necessary in 1915 to take stock of the available resources of manpower, in order to know both how many men were still available in the case of the passing of compulsory service acts, and how many men and women, trained for any kind of work other than military work and willing to serve the government in the present emergency, could be had in case of necessity. Consequently, the National Registration Act, enacted on July 15, 1915, provided for the establishment of a register of all persons, male and female, between the ages of fifteen and sixty-five, except those already serving in the army or navy. Every person resident in Great Britain (the Act does not apply to Ireland, except parts of Ulster) was required to fill up a form stating his or her name, residence, age, whether single or married, the number of dependents, occupa-

statutes, proclamations and other orders. A third edition of the Defence of the Realm Manual is revised to February 28, 1917. A monthly collection of Defence of the Realm Acts and Regulations has also been published by authority. 
tion, if any, and the employer's business, nationality, whether the work done by the person in question was for or under a government department, whether the person was skilled in, and able and willing to perform, any work other than the work at which he or she was at the time employed. It was also provided that any change of address of every person so registered should be communicated to the proper official, and that newcomers were to register within four weeks. Whether the National Registration Act has worked satisfactorily or not has been a somewhat debated question. It has certainly supplied the government with a large amount of important information.

When there came need of an army greater than that which could be furnished by voluntary recruiting, compulsory military service had to be introduced. The first Military Service Act, 1916, which received the royal assent on January 27, 1916, provided that every male British subject who on August 15, 1915. was ordinarily resident in Great Britain (the Act did not apply to Ireland) and had attained the age of eighteen years, and had not attained the age of forty-one, and on November 2, 1915, was unmarried or was a widower without any child dependent on fim, should, unless he was within the exceptions, or had attained the age of forty-one before the appointed date, be deemed as from the appointed date to have been duly enlisted in the regular forces for general service with the colors or in the reserve for the period of the war, and to have been forthwith transferred to the reserve. The burden of proof that the act did not apply to any individual rested on him.

There were established local tribunals, appeal tribunals, and a central tribunal, for granting certificates of exemption on the ground that it was expedient in the national interest that the applicant should continue his present work, or take up some special work, or continue his education, or on the ground that serious hardship would ensue for the man, owing to his exceptional financial or business obligations or domestic position, or on the ground of ill health or infirmity, or of a conscientious objection to the undertaking of combatant service. The certificates might be absolute, conditional or temporary; they might also be granted by government departments to men employed by them or for them; certificates are always reviewable and revocable.

The first Military Service Act provoked a certain amount of confusion because the tribunals in different parts of the country, 
undoubtedly animated by very patriotic motives, could not be expected to interpret the quite new rules and regulations in the same way, and, consequently, in some places exemptions would be granted under circumstances under which in other places they had been refused. The government issued a great number of supplementary rules intended to simplify proceedings and to remove misunderstandings.

Very largely under the pressure of public opinion, another Military Service Act, the Military Service Act, 1916 (Session 2), enacted on May 25, 1916, extended the principle of the first Act from British subjects who had not been married at a certain date to all male British subjects who at any time since August 14, 1915, had been, or for the time being were, ordinarily resident in Great Britain (the Act does not apply to Ireland), and had attained the age of eighteen years and had not attained the age of forty-one, unless they were within the exceptions. It was also provided that the Reserve and Territorial forces should remain with the colors until the end of the war.

In order to review the exemptions which might appear no longer justifiable, owing to the progress of the war, the more pressing need of men and the necessity of reducing the standard of requirements, there was then passed the Military Service (Review of Exceptions) Act, 1917. It applies to men who had been discharged or rejected or had been declared unfit for foreign service, and, with certain exceptions, requires such men to present themselves upon summons for re-examination.

The Military Service Acts apply, of course, only to men of what is considered military age. Men above or below that age, or men prevented by slight physical defects or by the nature of their employment at home from joining the army and going to the front, have practically since the beginning of the war been keen on helping in the release of troops for service at the front and also on helping in the organization of defense troops for the very remote, but not quite impossible, event of invasion by the enemy. The volunteer corps had already proved efficient organizations when the Volunteer Act, 1916 (enacted on December 22, 1916) provided that agreements entered into by members of volunteer corps to attend drills or undergo training or undertake military duties should be enforced by military courts and that such members during the training, drill, or performance of the military duties should be subject to military law. This Act is intended to organize 
the volunteers on a military basis, give them official recognition and enable the government to count upon their assistance in cases of need.

The creation of an enormous new army made very acute the problems of separation allowances for the wives and children of soldiers, whether volunteers or conscripts, of pensions for the dependents of men killed or permanently disabled in the war, and of pensions for disabled men themselves. Separation allowances have been paid very liberally. The underlying principle was that the government would pay wives and children of the soldiers several times the sum which the soldier himself was to give out of his pay. The rules as to separation allowances and pensions have been changed several times, and in addition there was passed in the course of 1915 the Naval and Military War Pensions, etc., Act, 1915. Under that act a committee was formed, called the Statutory Committee of the Royal Patriotic Fund Corporation. Subordinated to that Committee were local committees. The object of the committees was to decide questions of fact as to war pensions, and to make supplementary grants where grants out of public funds would prove inadequate. Such grants were to include the supplementing of pensions, separation allowances and other government grants. The committees were also to make grants or separation allowances where no grants or separation allowances from the government were payable at all, and out of their funds they were to make advances on pensions, grants, or separation allowances due at a later date from the government. The committees were to make provisions for disabled officers and men after they had left the service, including provisions for their health, training and employment. The local committees were to help the central committee and to exercise a certain amount of discretion in distributing funds. An important function seems to have been to collect funds from the public in order to strengthen the financial power of the Committee. In the course of 1916 a special ministry, the Ministry of Pensions, was created in order to regulate on a uniform basis the payment of pensions, etc. ${ }^{4}$

The Courts (Emergency Powers) (Amendment) Act, 1916, enacted on May 17, 1916, was meant to protect the financial affairs

* The Statutory Committee, which was for a time subordinated to the Ministry of Pensions, has now ceased to exist. 
of officers and men of the British forces. It was realized that, while they were fighting, it was not fair to let their debts be collected without regard to the fact that such collection might result in the ruin of the officers and men and their families. Under the Act no execution or other enforcement of judgment can be had against an officer or man of the British forces for a sum of money due and payable in pursuance of a contract, whether made before or after the outbreak of the war, except by special permission of a competent court, which has absolute discretion, after considering all the circumstances of the case and the position of the parties, to stay the execution. No distress may be levied, no right of re-entry, foreclosure, no other means of enforcing payment or recovery may be used against an officer or man without a similar application to a competent court which has the same discretion. Likewise a bankruptcy petition can be proceeded upon only upon an application which is again decided upon by the court according to its absolute discretion. ${ }^{5}$

On the other hand, any officer or man who is tenant of any premises under a tenancy from year to year, or for any longer period, may apply to the proper court for leave to determine the tenancy and the court may, in its absolute discretion, after considering all the circumstances of the case and the position of all the parties, by order authorize the applicant to determine the tenancy by such notice and upon such conditions as the court thinks fit.

\section{SUPPLIES FOR THE FORCES.}

One of the first steps taken by the government at the outbreak of the war (August 4, 1914), was the assumption of control over all the railroads of Great Britain. That step was obviously necessary, and because of strikes and other difficulties, it had to be followed by the taking over of coal mines two years later, in November. 1916. In December, 1916, shipping was placed under a new minister, the Shipping Controller, who has the function of monopolizing the control of shipping.

The organization of the huge armies rested for the first two

5 This yart of the Act corresponds with the Courts (Emergency Powers) Act, 1914, which is mentioned below. But in the case of officers and men of the forces the unfavorable position need not have arisen by reason of circumstances attrilutalle directly or indirectly to the present war. The following part, which deals with determination of tenancy, has 110 application at all in the case of civilian tenants. 
years in the hands of Lord Kitchener, but it was found early in the war that the supply of munitions had to be much greater than was originally anticipated, and consequently it was considered necessary to establish a special Ministry of Munitions, at the head of which stood for a time the greatest organizing genius of contemporary Britain, Mr. Lloyd George. The Ministry of Munitions was created by an act dated June 9, 1915. Its existence is to cease, at the latest, twelve months after the conclusion of the present war. Very soon after the creation of the Ministry, an act called the Munitions of War Act, 1915, was passed in order to facilitate more efficient organization of the munition supply. Under that act it was provided that no lock-out or strike could take place as a result of disputes as to wages, hours of work, or otherwise as to terms or conditions of, or affecting, employment on the manufacture or repair of arms, munitions, ships, vehicles. aircraft or other articles required for use in war, or of metals, machines or tools required for that manufacture, or on any other work, if the King by proclamation had made the Act applicable because in the King's opinion the dispute was directly or indirectly prejudicial to the manufacture, transport or supply of munitions of war. It was provided that such disputes were to be reported to the Board of Trade, which might refer them to an arbitrator or court of arbitrators agreed upon by the parties or fixed by the Board of Trade, or both. Strikes or lock-outs would become lawful only if such dispute were not so referred for settlement within twenty-one days after having been reported to the Board of Trade.

By the same Act the Minister of Munitions was authorized to declare that an establishment in which munitions were manufactured was a "controlled establishment," and in such cases he was authorized to limit the profits, suspend rules as to limitations of output, and make other regulations; the owner of the establishment would be deemed to have consented to the restricting rules set out in the Act. By "munitions" are meant practically all articles necessary for the successful prosecution of the war.

Munitions tribunals were established, composed of chairmen appointed by the Minister of Munitions and of men chosen by the Minister from panels representing in equal numbers the employers and employees. The tribunals were put in charge of "all offences and matters" under the Act.

Under the emergency legislation the Government has come to 
be, directly or indirectly, an employer of labor on an unprecedented scale. Both workmen and employers have been put under much restraint. The Trade Unions have indeed agreed voluntarily to have many of their rules suspended, but on the other hand it was realized that the new conditions, the entry into the factories of vast hosts of untrained and unorganized workmen, necessitated state rules under which the health and the general position of the workmen could be cared for properly. Many measures have had to be taken to insure that the workmen will be properly paid, properly fed, and otherwise cared for. Examples of such measures will be found, among others, in the Police, Factories, etc. (Miscellaneous Provisions) Act, 1916, which enables the Home Secretary to make far-reaching rules as to most of these subjects and which makes the application of such rules sometimes dependent upon a request of the workers themselves or of a proportion or number of them.

The increasing size of the army, the heavy casualties calling for new men to fill the gaps, the munition works established on an unprecedented scale, the necessity of building up British agriculture to provide an increased food supply, not only because of the submarine danger, but also because the existing tonnage is needed for transportation of troops and munitions, all this resulted in a necessity for the government to use all available hands. Everybody could help-men and women, old and young. Many women, and many men above military age or unfit for military service, offered their services to the government; the question was, how to use their hands or their brains in the best way. "For the purpose of making the best use of all persons, whether men or women, able to work in any industry, occupation, or service," the Ministry of National Service was created by the Ministry of National Service Act, 1917. The Act provided, however, that no Order in Council or regulation should authorize the compulsory employment or transfer of any person in or to any industry, occupation, or service, or should impose any penalty for any breach of a voluntary agreement made by any person with the Minister of National Service, whose official title is DirectorGeneral of National Service. ${ }^{6}$

6 The Billeting of Civilians Act, 1917, (enacted on May 24, 1917) is an interesting illustration of the way in which workers far away from the battlefield have to be taken care of in the interest of modern warfare. A Central Billeting Board (on which at least two seats are 


\section{Maintenance of Order and Prevention of Demoralization.}

It is obvious that the strain of the war must have resulted in many difficulties, so far as the work of the courts of law, among other things, was concerned. One of the chief complaints has been that, while every hand was needed for war service, many citizens had to spend their time on juries, the work of which could be accomplished by fewer men. Without changing the general rule as to petty juries, ${ }^{7}$ the Grand Juries (Suspension) Act, 1917, directs that no grand juries shall henceforth be summoned, but that where a person has been committed for trial or where the consent or direction in writing of a judge of the High Court of Justice or of the Attorney-General or Solicitor-General for the presentment of an indictment has been given, an indictment may be presented without having been found by a grand jury. This act does not extend to Scotland or Ireland, and is to remain in force only during the continuance of the present war and six months after the termination of the war. ${ }^{8}$

It was found necessary to provide a larger number of constables to supervise certain buildings of public importance, and, apart from that, many policemen had volunteered for service with the colors and had to be replaced. Under the Statute of 1831, special constables (civilians who offered their services for police work during certain hours of the day or night) were used

reserved for women) is to take charge of the question of billeting civilians, wherever any Goverument department certify that the carrying on of any work is of national importance for the purposes of the present war and necessitates the provision of accommodation in any locality for persons employed on that work (which may be munitions work or any other kind of work). The Act prescribes in detail how the Board shall form local committees and make regulations for them, it makes it compulsory for the occupier of any premises within a locality where the Act is in operation to give to the local committee any information reasonably required of him, to provide (if required to do so under the Act) billets, attendance, and meals or food for the persons billeted; the Act also lays down rules as to the settlement of disputes, as to the behavior of persons billeted, and as to compensation and other payments due to the occupier of the premises. The Act, furthermore, contains rules as to cases in which billeting can not take place without the consent of the occupier of the premises. The Act does not extend to Ireland.

${ }^{7}$ As to the possibility of trying persons by court-martial for alleged offences against the Defence of the Realm Acts and Regulations, see below.

8 The Coroners (Emergency Provisions) Act, 1917, placed on the Statute Book in May, 1917, likewise as a temporary measure, lowers the number of persons who are summoned to serve as jurors at a coroner's inquest, from between twelve and twenty-three to between seven and eleven. 
to fill the need of policemen. Men above military age or men otherwise prevented from serving with the colors offered their services in large numbers; the Special Constables Act, 1914, together with Orders in Council based on it and relating to special constables, organized this force which appears to have worked very satisfactorily.

One of the great difficulties which the government had to face since the early stages of the war was the question of liquor traffic. Wives of soldiers, especially of those coming from the poorest classes of society, found themselves in regular receipt of sums of money larger than had ever been earned by their husbands in peace time. It was found that they, and also the munition workers, who are paid very liberally, would sometimes spend their pay, at least in part, on liquor, with the result not only that their pay was wasted, but that their working ability was weakened. Under the Defence of the Realm (Amendment No. 3) Act, 1915, Orders in Council were made establishing the Central Control Board (Liquor Traffic). The Board was invested with the power of closing licensed premises and clubs, of regulating the hours during which such premises or clubs might be open at all, or might be open for the sale or supply of intoxicants, of prohibiting such sale or supply on any premises or in clubs, of imposing restrictions or conditions, and generally of regulating the introduction and transport of intoxicants. The Board was also authorized to monopolize the sale and supply of intoxicants, to establish refreshment rooms, to acquire premises by compulsion. The Board issued regulations for each of twelve specified areas, and each contravention of the regulations was to be punished with imprisonment with or without hard labor for six months, and (or) a fine of one hundred pounds.

Steps have been taken to prevent the disorganization which usually results from political struggles. With millions of voters fighting "somewhere in France," with the local party organizations either asleep or hardly able to undertake political fights without diverting attention from some important war work, parliamentary elections so far as possible, and even local elections. have had to be postponed. The revision of the parliamentary register was at first postponed, and afterwards, in 1916, not, indeed, ordered, but allowed. The life of Parliament has been repeatedly prolonged (each time for seven or eight months), by statutes without which the present Parliament would have termi- 
nated some fifteen months ago, ${ }^{9}$ and which have provided similarly for the postponement of local elections (Elections and Registration Act, 1915; Parliament and Registration Act, 1916; Parliament and Local Elections Act, 1916). ${ }^{10}$

During the war numerous changes have occurred in the personnel of the government, many ministers having either resigned or changed departments. As nearly all ministers who are members of the House of Commons, as soon as they accept a new office of profit under the Crown, automatically lose their seats, several acts were passed (Re-election of Ministers Act, 1915; Re-election of Ministers Act, 1916; Re-election of Ministers (No. 2) Act, 1916), temporarily suspending the operation of this rule, so as to enable the ministers to retain their seats and avoid the necessity of a by-election.

The British public has been very generous whenever appeals were made to it to contribute funds or gifts in kind, either for British or for Allied charitable purposes. As it appeared that the generosity of the public was sometimes taken advantage of by impostors, the War Charities Act, 1916, laid down rules as to the registration of war charities and their supervision.

\section{Protection of the Country.}

At the outbreak of the war a statute called Aliens Restriction Act, 1914, authorized the King to make regulations by Order in Council for restricting the landing, embarkation, or residence of aliens in certain areas, or the movements generally of all aliens or classes of aliens, for registration of aliens and for other measures necessary for the exercise of what might be called aliens' police. Under that act Orders in Council were first made requiring the registration of all alien enemies, that is, subjects of enemy states. Alien enemies were forbidden to travel beyond five miles from their registered address without permit. They were required to notify the police whenever they were about to change their address. Later the duty of registration was extended to all persons, whether aliens or not, coming to boarding-houses, lodging houses, hotels and inns of any description, but such registration, apart from the case of alien enemies who had also to register with the police, meant only the duty of filling up certain forms which

9 This was in April, 1917.

${ }^{10}$ Cp. Parliament and Local Elections Act, 1917. 
were to be kept by the landlord. The duty of registration with the police was extended, by request of the Belgian government, to Belgian refugees, in order to prevent abuses of English hospitality by enemy agents. Finally, rules were made requiring all aliens to register with the police of the district in which they resided (apart from registering at the boarding-houses, hotels, etc.), and to carry identity books issued by the police, containing a photograph and personal description of the alien, and statements as to nationality of his wife and parents, as to any near relations serving with or against the allies, and other details.

From the very first, there was specified a number of "prohibited areas," in which no aliens could reside without registering with the police, while alien enemies could reside there only by special permission of the local police, granted in exceptional cases. Alien enemies were forbidden to have in their possession firearms, or other weapons, ammunition, explosives, petroleum and other inflammable liquids in quantities exceeding three gallons, any signalling apparatus, motor cars, motor-cycles, motor-boats, yachts, air-craft, telephones, cameras, military or naval maps or handbooks, and cipher codes. Restrictions were placed on the circulation among alien enemies of newspapers in enemy language, and also on the carrying on of any banking business by alien enemies.

It was the policy of the government at first not to intern alien enemies excepting when they were either actually suspected, or destitute. Later on, about the middle of 1915, general internment was decided upon. Internment was to extend only to males of military age; all other alien enemies of both sexes were to be deported. But Advisory Committees, presided over by judges of the High Court, were appointed to make recommendations to the Home Secretary upon applications for exemption. The policy of the Advisory Committees has been to grant exemptions to people who could prove that their remaining at liberty in the country was in the public interest, for instance, because of the character of the work in which they were engaged, or else because they were proved to be heartily in favor of the Allies. The Committees also usually recommended for exemption men who were supporting British-born wives and large families and who could establish their claims to be perfectly harmless. But, above all other exemptions, it has been the policy of the government to grant exemptions to men who, while technically the subjects of the enemy, were, by reason of their nationality, con- 
sidered friendly and not enemy aliens. To this category belong the Bohemians, Slovenes, Serbs and Croats who are technically subjects of Austria or Hungary, Poles who are technically subjects of Austria or Germany, Alsatians, Danes from Schleswig, and subjects of Turkey such as Armenians and Greeks. In most of these cases the government favored the establishment of committees, e. g., the Polish Information Committee and the Southern Slav Committee, which were to report to the Advisory Committee whether the claim of any applicant to be a member of the given nation was justified or not. Thousands of exemptions were granted on the ground of such reports.

Another important group of acts is the Defence of the Realm Acts. The rules enacted in the early part of the war were consolidated in the Defence of the Realm Consolidation Act, 1914, under which the King in council was empowered to make regulations during the present war for securing the public safety and the defence of the realm. He was at first empowered to authorize by such regulations the trial by court-martial, or in the case of minor offenses, by courts of summary jurisdiction, of persons committing offences against the Defence of the Realm Regulations. The trial by court-martial was to proceed as if the defendant were a person subject to military law and had, on active service, committed a military offence. The death penalty was threatened when it would be proved that the offence had been committed with the intention of assisting the enemy. The provision as to the trial of British civilians by court-martial aroused opposition in the House of Lords, especially on the part of a prominent judge, Lord Parmoor. Finally, the government introduced a bill which was passed as the Defence of the Realm (Amendment) Act, 1915. By that Act, British subjects who were civilians were given the right to claim a trial by civil court with a jury. The courts were given the power of excluding the public from any part of the hearing whenever that was asked for by the prosecution in the interests of national safety. In the event of invasion or other special military emergency arising out of the present war, the King was empowered to suspend by proclamation the right of civilians to demand a civil court with a jury, either generally or in any specific area. The Defence of the Realm Acts also authorized the Admiralty and War Council to require that there should be placed at their disposal the whole or any part of the output of any factory or workshop in which arms, ammunition or war- 
like stores or equipment, or any articles required for the production thereof, were manufactured. The Admiratly and War Council were even authorized to take possession of, and use for naval or military service, any such factory or workshop, or any plant thereof.

Under the Defence of the Realm Acts, regulations have been issued, the main body of which is represented by the Defence of the Realm (Consolidation) Regulations, 1914. The underlying principle was that the ordinary avocations of life and the enjoyment of property would be interfered with as little as might be permitted by the exigencies of the measures required to be taken for securing the public safety and the defence of the realm. Ordinary civil cases were to be dealt with by the civil tribunals in the ordinary course of law.

Competent naval or military authorities were authorized, for securing the public safety or the defence of the realm, to take possession of movable or immovable property of any description, to use land for training, to stop up roads, to require the removal of movables from any area, to take possession of, or requisition the output, of factories manufacturing arms, munitions, etc., to require the extinguishment of lights, to require inhabitants to remain indoors and to remove suspects from specified areas. It was forbidden without lawful authority to collect, record, publish or communicate, or attempt to elicit, any information with respect to the movement, numbers, description, condition, or disposition of any of the British or allied forces, ships, or war materials, or with respect to the plans or conduct or supposed plans or conduct of any naval or military operations by such forces or ships, or with respect to any works or measures undertaken for or connected with or intended for the fortification or defence of any place, or any other information intended to be communicated to the enemy, or of such a nature as was calculated to be, or might be, directly or indirectly useful to the enemy. It was prohibited to have in one's possession, or to carry, or to liberate any carrier or homing pigeons, to possess a wireless telegraphic apparatus, or to buy, or sell, or control one, or to transmit otherwise than through the post, or receive or to have in one's possession for such transmission or conveyance, any letter or written message to or from the United Kingdom. It was prohibited without lawful authority, to be in possession of any searchlight, semaphore or other apparatus intended for signalling, whether 
visual or otherwise, or to display, erect, or use any signal, or display lights, or use fireworks which might serve as a signal, guide, or landmark. It was likewise prohibited to spread false reports, or make false statements, or spread any reports or make any statements, whether by word or mouth, or in writing or in any newspaper, periodical, book, circular or other printed publications, likely to cause disaffection to the King, or to interfere with the success of the forces by land or by sea, or to prejudice the King's relations with foreign powers, or to spread reports or make statements likely to prejudice the recruiting, training, discipline, or administration of any of the forces. Other rules relate to the possession or carrying of arms, inflammable articles, injury to railroads or military works, etc. Provision was likewise made against supplying intoxicants, including sedatives, narcotics or stimulants, to members of armed forces for the purpose of eliciting information to be communicated to the enemy or for any purpose calculated to assist the enemy, or with the intent of making members of the armed forces drunk, or less capable of the efficient dișcharge of their duties.

Further regulations (e. g. June 10, 1915; July 6. 1915; July 28, 1915) gave the Home Secretary and the Secretary for Scotland powers for regulating lighting. On the recommendation of a competent naval or military authority, or an advisory committee, the Secretary was empowered to intern, or prohibit to leave an area, or to enter an area, or otherwise to subject to restrictions, any person (whether British subject or otherwise) in view of his hostile origin or associations, whenever it might be expedient for securing the public safety or the defence of the realm. Penalties were imposed upon people who had been in communication, or had attempted to communicate, with a spy, unless it were proved that they did not know and had no reason to know that such person was a spy. Penalties were also imposed upon people wearing, without authority, naval, military, police, or other official, uniforms, decorations, medals, or badges, or any of them so nearly resembling the official ones as to be calculated to deceive, on persons supplying such uniforms, decorations, medals, badges, or representing themselves to be authorized to wear them, as well as on persons tampering with passports, certificates, etc. New regulations are constantly being issued as need arises. Their contravention is a contravention of the Defence of the Realm Acts. 


\section{Weakening of the Economic Power of the Enemy.}

The rules as to naval prizes under international law made it necessary to establish, at an early stage of the war, prize courts according to statutes which had been previously in existence. The work of the prize courts has also been regulated by statutes and ordinances during the war. The institution of naval prizes tends, of course, to weaken the economic power of the enemy. But the most important rule under the common law has been the rule prohibiting trading with the enemy,-in other words, prohibiting any commercial intercourse, not as in former ages with subjects of an enemy state or sovereign, but with all persons of whatever nationality or of whatever allegiance residing on enemy territory or on territory in enemy occupation. This territorial, instead of personal, principle has been extended so far as to exclude territory which had been taken by the allied forces from the enemy, while on the other hand, "enemy territory" includes, e. g. those parts of Belgium which are in German occupation. The original proclamation as to trading with the enemy issued at the outbreak of the war reminded British subjects and residents of the British empire of their duty not to trade with the enemy. It has been followed by Trading with the Enemy Amendment Acts, 1914, 1915, 1916. Those acts not only defined and extended the duties of residents of Great Britain not to trade with the enemy, but they also made provision for the administration of enemy property in the United Kingdom. The policy of the British government has been not to interfere with the property of alien enemies resident in Great Britain, but to place in the hands of a custodian property of persons residing or carrying on business on enemy territory. In 1916, however, a statute authorized the winding up of businesses carried on for, or under the control of, enemy subjects. Enemy banks which had branches in England, for instance the German Bank, the Dresden Bank, etc., were given permission to carry on their business only in so far as that was necessary to complete transactions entered into before the war and to fulfill obligations toward British subjects and neutrals. Later on, the principle of forbidding commercial intercourse with the enemy was extended to intercourse with firms residing in neutral countries but being really enemy firms or transacting business with, or acting as agents of, firms on enemy territory (Trading with the Enemy (Extension of Powers) Act, 1915.) The famous 
"black list" was but a list of firms in neutral countries with which, because of their enemy nationality or association, "all persons or bodies of persons resident, carrying on business, or being, in the United Kingdom" were forbidden to transact business.

The Registration of Business Names Act, 1916, was passed for the purpose of compelling the registration of firms not trading under the names of their partners, or of men not trading under their own names, or trading under changed names. Power was given to the proper authorities to prohibit the use of the word "British" in the name of the firm, where such word would give a wrong impression as to the nationality of the firm or the merchant. ${ }^{11}$

Strengthening the Economic Power of the Country.

The modern war is a war not only of soldiers but also of bankers. It was realized in England at the outbreak of the war that the catastrophe which had come suddenly would result in an economic upheaval. Consequently, steps were at once taken to preserve the economic balance by closing the banks for a few days and by passing the Postponement of Payments Act, 1914, which enabled the King to issue proclamations authorizing the postponement of payment of bills of exchange, or of any negotiable instruments, or of other payments in pursuance of any contract (the postponement authorized by the several proclamations issued under this Act terminated on November 4, 1914). In order to strengthen the financial position of the empire, it was also considered necessary to concentrate gold in the Bank of England and to issue treasury notes for ten shillings and twenty shillings as well as to make postal orders legal tender for a time. All these steps, with the exception of the concentration of gold and the introduction of treasury notes, were of a strictly temporary character and hardly survived the year 1914 .

On the other hand, it was soon realized that the war would affect very many business men and also many poor men or men depending on scant incomes which would diminish because of the turmoil. The Courts (Emergency Powers) Act of August 31, 1914, provides that if the proper court is of opinion that time should be given to a debtor under a life or endowment policy

${ }^{11}$ See a note by Sir Frederick Pollock in the Law Quarterly Review, April, 1917, p. 115, on this statute, which is only in part a war measure. 
not over twenty-five pounds, the premiums of which are payable at not longer than monthly intervals, and have been paid for at least two years immediately preceding the outbreak of the war, and if inability to pay is due to circumstances arising directly or indirectly out of the present war, the court may, in its absolute discretion, after considering all the circumstances of the case and the position of all the parties, stay execution or defer the operation of all remedies ordinarily at the disposal of the creditor, for such a time and under such conditions as the court may direct. Similarly, where a bankruptcy petition has been presented against any debtor and the debtor proves to the satisfaction of the court that his inability to pay is due to circumstances attributable directly or indirectly to the present war, the court may stay the proceedings for such time and subject to such conditions as it may direct. The same Act was made applicable to all proceedings for the recovery of possession of small tenements as if they were in all cases proceedings for the payment or recovery of a sum of money due and payable on account of rent. ${ }^{12}$

The Increase of Rent and Mortgage Interest (War Restrictions) Act, 1915, which (like the act just mentioned) is to be in force for the period of the war and for six months thereafter, and applies mainly to small and medium-sized dwelling-houses. makes irrecoverable any increase in rent (except where otherwise an injustice would follow, e. g., if the landlord had incurred expenditure in improvements; in this latter case, the increase can only amount to six per cent. per annum on the amount so expended). or in interest on mortgages, on such dwelling-houses, and as long as the tenant or the mortgagor complies with the agreement in accordance with the Act, no order for recovery of possession or for the ejectment of the tenant can be obtained and no mortgage may be called in except under special circumstances which the court has to take into consideration. Rents paid by the tenant contrary to the Act (e. g., if the landlord refuses otherwise to renew the agreement) are recoverable or can be deducted. ${ }^{13}$

An interesting effort to save not only individual energy but also the stocks of coal, was the Summer Time Act, 1916, under

12 The Courts (Emergency Powers) (No. 2) Act, 1916, was intended to broaden the scope of the Act of 1914 and prevent some liardships. As to the Courts (Emergency Powers) (Amendment) Act, 1916, which relates to officers and men, see above.

13 The details of the Act must be omitted in this exposition. 
which, on an appointed spring day, all clocks were set back one hour, and were advanced again one hour on October 1. This daylight saving measure has certainly helped, to some extent, to promote the purposes of national economy, and has been adopted again in the current year.

The progress of the war has made it necessary to impose restrictions on the consumption of food-stuffs. One of the first restrictions was contained in the Output of Beer (Restriction) Act, 1916, amended by the Output of Beer (Restriction) Amendment Act, 1916. Under those acts the output of brewers is now limited, it seems, to 70 per cent. of their previous output, thus reducing the amount of foodstuffs used for the production of beer. At the end of 1916 and since the beginning of 1917 rules have also been laid down limiting the number and prices of meals in restaurants and otherwise designed to prevent waste.

Ludwik Ehrlich.

University of California, Berkeley, California. 




\section{UNTVERSITY OF CALIFORNIA LIBRARY BERKELEY}

\section{THIS BOOK IS DUE ON THE LAST DATE}

\section{STAMPED BELOW}

Books not returned on time are subject to a fine of $50 \mathrm{c}$ per volume after the third day overdue, increasing to $\$ 1.00$ per volume after the sixth day. Books not in demand may be renewed if application is made before expiration of loan period.

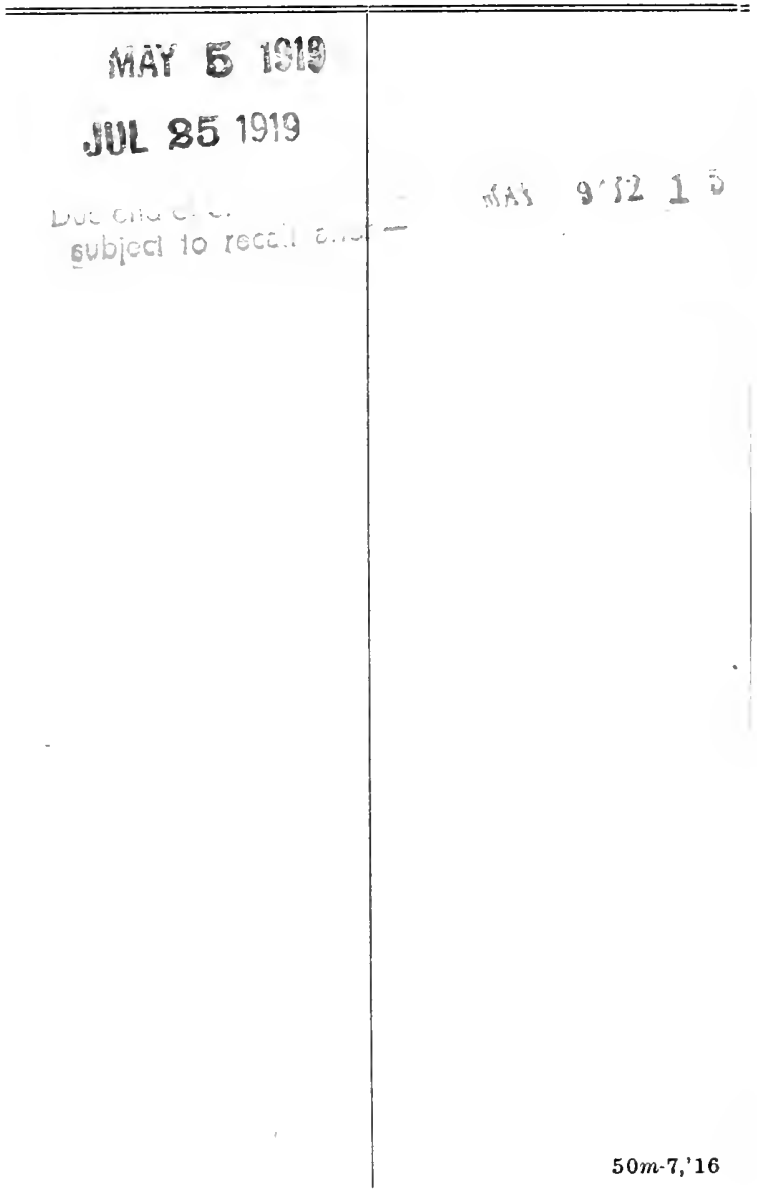


Gaylord liros.

Makers

Syracuse, N. I.

PAT. JAN. 21, 1908 winillitilitit.

C0512 30651

UNIVERSITY OF CALIFORNIA LIBRARY 


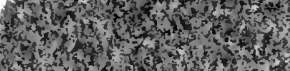

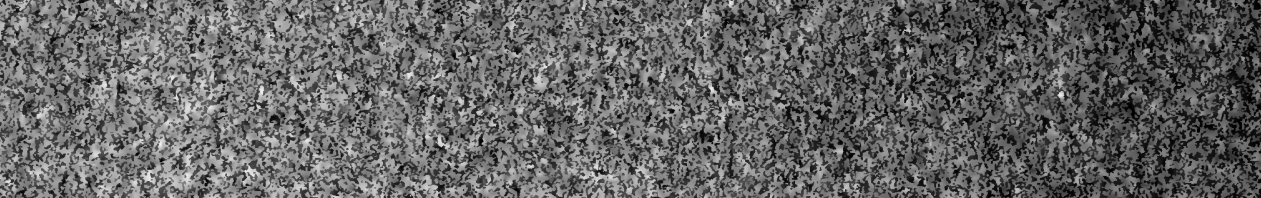
. H.t.

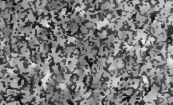

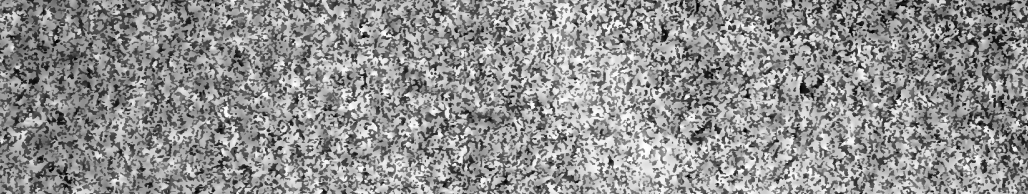

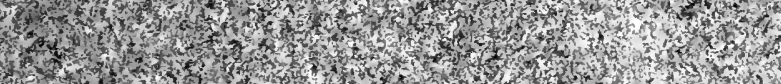
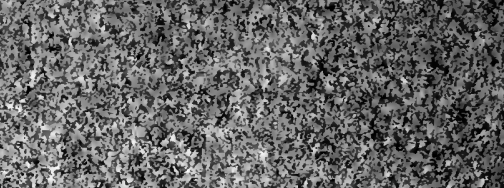

$4 x$ H.t.

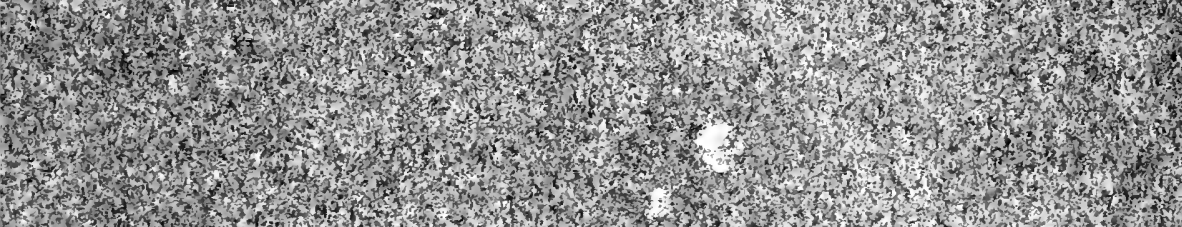

3.7.7.

$n$
1

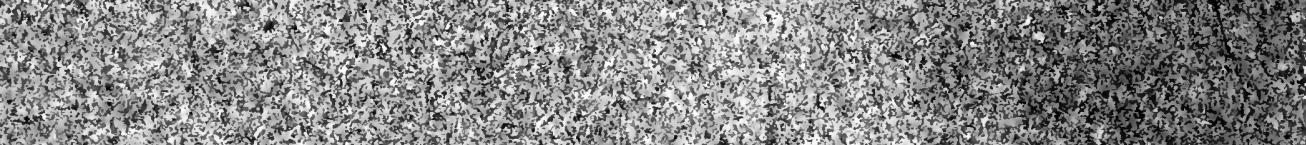

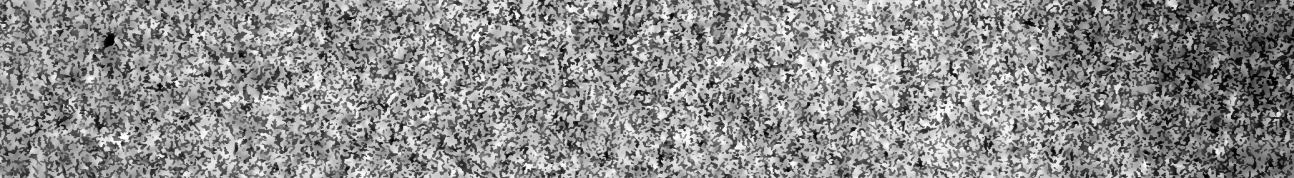

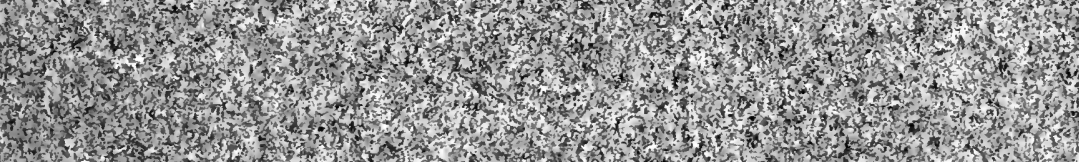

1.7. (n) th

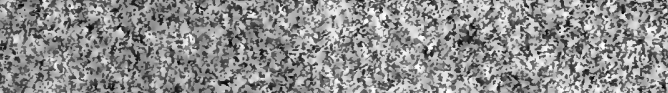

3
m.

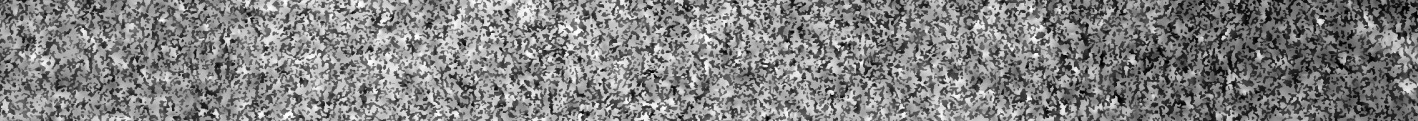
1.7.

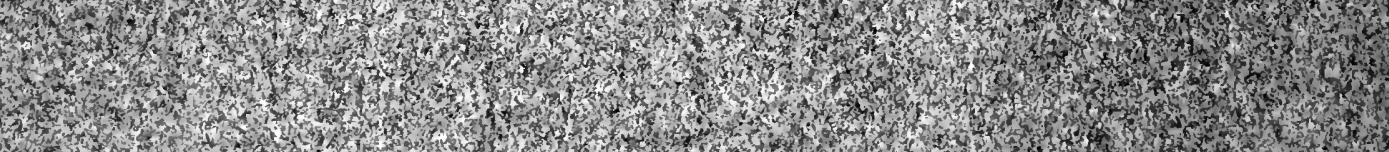

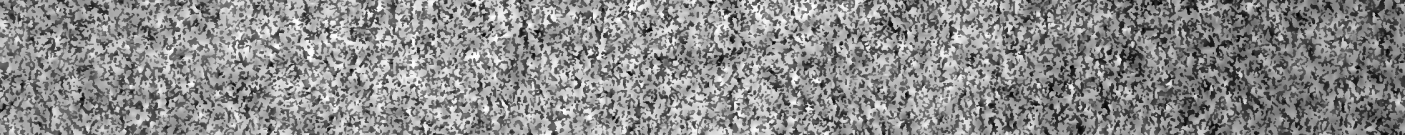

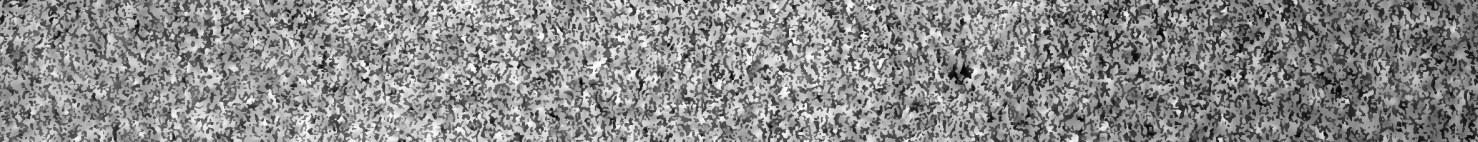
7.

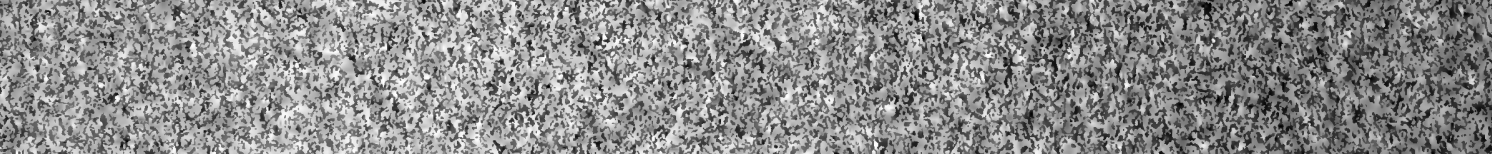
7.

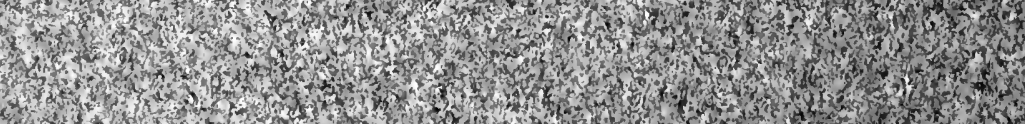

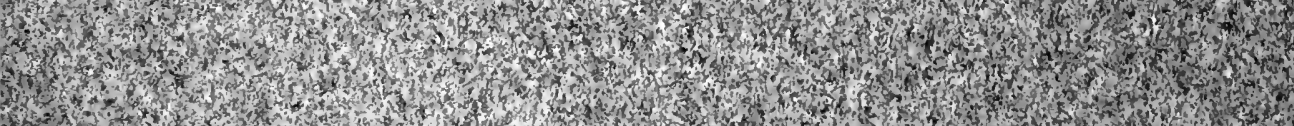

